\title{
Effect of Educational Program on Pressure Ulcer Prevention Intervention among Nurses of Intensive Care Units at a Public Hospital, Pakistan
}

\author{
N. Hassan (Nasira Hassan), M. Afzal (Muhammad Afzal), S. Sehar (Sana Sehar), \\ A. Gilani (Amir Gilani)
}

Lahore School of Nursing, The University of Lahore, Pakistan.

\section{E-mail address:}

heraabhati@gmail.com

\section{Reprint address:}

Nasira Hassan

Lahore School of Nursing

The University of Lahore

Pakistan

Source: Clinical Social Work and Health Intervention

Volume: 11

Issue: 4

Pages: $38-45$

Cited references: 16

\section{Reviewers:}

Selvaraj Subramanian

SAAaRMM, Kuala Lumpur, Malaysia

Harald Stefan

Vienna General Hospital, Vienna, Austria

\section{Keywords:}

Intensive Care Units (ICU). Pressure Ulcer (PU). Pressure Ulcer Prevention Intervention (PUPI). Infection Control Parameters (ICPs).

\section{Publisher:}

International Society of Applied Preventive Medicine i-gap

CSWHI 2020; 11(4): 38 - 45; DOI: 10.22359/cswhi_11_4_05 (C) Clinical Social Work and Health Intervention

\section{Abstract:}

Objective: The purpose of this study is to evaluate the effect of an educational program on pressure ulcer prevention intervention among nurses in intensive care units at a public hospital in Pakistan.

Design: It is a Quasi experimental study.

Participants: 144 staff nurses with different educational backgrounds working more than 6 month in an intensive care units were participants.

Methods: They were evaluated pre-test. Workshops, lectures and hands on practice related to pressure ulcer prevention intervention were conducted. After these interventions post-tests were taken. 
Results: There was a major difference between the mean knowledge score about the pressure ulcer preventive measures among nurses before $(5.73 \pm 1.488)$ and after (12.01 \pm .908$)$ education sessions. P value is 0.000 which was less than .001 shows a significant difference in mean knowledge score before and after the education.

Conclusion: Knowledge base practices improved the quality of life and care. In the current study, post-test knowledge of nurses after a seminar, lecture and literature which given by the researcher, show improvement and most of the nurses get high marks in post-test session.

\section{INTRODUCTION}

Localized damage to skin tissue due to prolonged and extensive weight on bony eminences is called a pressure ulcer (Zeb et al., 2015). Pressure ulcer is a communal and excruciating health condition of immobilized patients (Uba, Alih, Kever, Lola, 2015). Pressure ulcers effect people all over the world (Hsu, Tsao, Sung 2013).

In health care organization's education is considered as a first step in prevention from pressure ulcer. Knowledge amongst nurses show a vital role in the prevalence of pressure ulcer reduction, management and prevention in hospitals (Levine, Ayello, Zulkowski, Fogel 2012). In hospital setting where the nurses are skillful at risk assessment and planning of PU management, and implementation of prevention, the level of incidence of pressure ulcer is lower (Andrade et al., 2014). Educational intervention is a significant tool to enhance nurses' knowledge and to prevent PUs (Cox, Roche, Van Wynen 2011).

The pervasiveness of PU indicates that the most focused need of nursing care is prevention of pressure ulcers. The occurrence of PUs was $18.1 \%$ in different health care settings across 5 countries (Vanderwee, Clark, Dealey, Gunningberg, Defloor, 2007). PUs play an imperative role in spread of infection especially in hospital settings; increase patient morbidity; mortality rate; hospitalization. The important component of patient safety goals are to minimize the number of pressure ulcers (Mohamed, Weheida 2015).

In the USA, predictable cost of pressure ulcer treatment exceeds $\$ 11$ billion per annum (GraySiracusa, Schrier 2011). Nurses play an important role in prevention of PUs. A nurse is the person in clinical settings who early recognizes the signs and symptoms of PUs. They should plan a teach- ing program for patients to prevent PUs (De Meester, Van Bogaert, Clarke, Bossaert, 2013).

Educational intervention is an appropriate mechanism for transferring knowledge and awareness for nurses and patients (Brunner, Suddarth, Bare, Boyer, Smeltzer 1988; Masoumi, Masoumi, Shoujaei, Sharafi 2015). Moreover, nurses' knowledge enhancements reduce the cost of treatment; reduce pain; reduce human suffering (Smith, Waugh 2009).

Furthermore risk assessment, documentation, training, prevention and treatment guidelines are inadequate in nursing care relative to pressure ulcers (Saleh, Qaddumi, Anthony 2012). A survey was conducted in 16 Belgian hospitals to gain knowledge of nurses relative to PU. It was a cross sectional multicenter study using a valid and reliable questionnaire used to measure the results during February 2016 to December 2017. The result of this study revealed a low level of information of nurses regarding pressure ulcer prevention (De Meyer, Verhaeghe, Van Hecke, Beeckman 2019).

\section{METHODS}

\section{Research design}

A quasi experimental study design was used to explore the effect of an educational session of pressure ulcer prevention intervention among nurses of intensive care units. The study area was intensive care units at Lahore General Hospital Lahore.

\section{Participants}

The participants in this study was recruited through convenient sampling of 144 nurses were working in ICUs at Lahore General Hospital La- 
hore with different educational backgrounds who agreed to participate in this study.

\section{Research instrument}

The research instrument consisted of the following sections:

Section 1: socio-demographic data

Data characteristics of the nurses were age, sex, education, marital status and experience.

Section 2: Structured knowledge questionnaire

It was used to evaluate the nurse's knowledge about prevention of pressure ulcers of immobilized patients. A 13-item knowledge assessment instrument was offered to measure the knowledge of nurses regarding PU prevention.

Section 3: Teaching program

The teaching program was planning used to cover the knowledge and practice for prevention and management of pressure ulcers.

\section{DATA COLLECTION PROCEDURE}

After taking official written permission to conduct this study from head of department. The purpose and nature of the study was described before consent.

\section{Nurse's educational program}

The preparatory phase

After taking informed consent from nurses, socio-demographic data was collected. After that pre-knowledge assessment of nurses regarding pressure ulcer prevention was done with the help of a pre-test questionnaire. Time for filling of assessment questionnaire was about 20 minutes.

\section{Interventional Phase}

The second phase of this study was give education to nurses regarding pressure ulcer prevention through lectures. The educational program consisted of 8 sessions over 1 month. Each teaching session time was 2 hours. Each lecture was focused on the general knowledge of pressure ulcers. Participants were tsught through lecture, group discussion and questions. Printed material related to pressure ulcer prevention with guidelines was given to participants after eachteaching session.

\section{Evaluation phase}

An evaluation phase was started after teaching sessions to all groups of participants. The 13item knowledge questionnaire post-test was filled immediately after each lecture.

\section{RESULTS}

Table 1: Demographic Data of Participants Nurses pre and post Education

\begin{tabular}{lcc}
\hline Variables & Number $(\mathrm{n})$ & Per cent \\
\hline Gender: & & \\
Females & 144 & $100 \%$
\end{tabular}

Age:

20-25 years

68

47.2

26-30 years

62

43.1

31-35 years

12

8.3

36-40 years

2

1.4

\section{Experience:}

1-5 years

6-10 years

11-15 years

16-20 years

$\begin{array}{rr}124 & 86.1 \\ 15 & 10.4 \\ 1 & 0.7 \\ 4 & 2.8\end{array}$

\section{Qualification:}

General Nursing

Generic 4 Year BSN

Post RN 2 year BSN

Table 1 Reveals that all 100\% ( $\mathrm{n}=144)$ nurses were female. Age of Nurses were: $47.2 \%(n=68)$ age $20-25$ years; $43.1 \%(n=62)$ age $26-30$ years; $8.3 \%(n=12) 31-35$ years of age; only $1.4 \%(n=2)$ nurses 36-40 years of age. Experience wise majority were: having less experience $86.1 \%$ $(n=124)$ had experience $1-5$ years; $10.4 \%(n=15)$; 6-10 years and only $3.5 \%(n=5)$; had more than 10 years of clinical experience. Majority $96.5 \%$ $(\mathrm{n}=139)$ were: General Nursing Diploma holders:, $2.1 \%(n=3)$ were Generic BSN; $1.4 \%(n=2)$ were Post Rn BSN nurses.

Table 2: which statement is correct? a. Malnutrition causes pressure ulcer. b. A lack of oxygen causes pressure ulcers. c. Moisture causes pressure ulcers.

\begin{tabular}{|l|c|c|c|c|}
\hline Response & \multicolumn{2}{|c|}{$\begin{array}{c}\text { Knowledge } \\
\text { Before } \\
\text { education }\end{array}$} & \multicolumn{2}{c|}{$\begin{array}{c}\text { Knowledge } \\
\text { After } \\
\text { education }\end{array}$} \\
\hline & Frequency & $\%$ & Frequency & $\%$ \\
\hline Wrong & 117 & 81.3 & 26 & 18 \\
\hline Correct & 27 & 18.8 & 118 & 82 \\
\hline
\end{tabular}


Above Table 2 reveals that on a question of the cause of pressure ulcer development pre-education only $18.8 \%$ gave correct responses that lack of oxygen causes pressure ulcers which increased to $82 \%$ correct responses after the education for preventive pressure ulcer measurements.

Table 3: Extremely thin patients are more at risk of developing a pressure ulcer than obese patients. a. The contact area involved is small and thus the amount of pressure ulcer is higher. $\mathbf{b}$. The pressure is less extensive because the body weight of patients is lower than the body weight of obese patients. c. the risk of developing the vascular disorder is higher for obese patients, this increases the risk of developing pressure ulcers.

\begin{tabular}{|l|c|c|c|c|}
\hline Response & \multicolumn{2}{|c|}{$\begin{array}{c}\text { Knowledge } \\
\text { Before } \\
\text { education }\end{array}$} & \multicolumn{2}{c|}{$\begin{array}{c}\text { Knowledge } \\
\text { After } \\
\text { education }\end{array}$} \\
\hline & Frequency & $\%$ & Frequency & $\%$ \\
\hline Wrong & 89 & 61.8 & 1 & 0.7 \\
\hline Correct & 55 & 38.2 & 143 & 99.3 \\
\hline
\end{tabular}

Above Table 3 suggests that why very thin patients are at greater risk of developing pressure ulcer which was correctly replied by $38.2 \%$ before education, who knew that the contact area involved is small and thus the amount of pressure is higher while $99.3 \%$ participants replied correctly after the education session.

Table 4: What happens when a patient, sitting in bed in a semi-upright position $\left(60^{\circ}\right)$, slides down? a. Pressure increases when the skin sticks to the surface. b. Friction increases when the skin sticks to the surface. c. Shearing increases when the skin sticks to the surface.

\begin{tabular}{|l|c|c|c|c|}
\hline Response & \multicolumn{2}{|c|}{$\begin{array}{c}\text { Knowledge } \\
\text { Before } \\
\text { education }\end{array}$} & \multicolumn{2}{c|}{$\begin{array}{c}\text { Knowledge } \\
\text { After } \\
\text { education }\end{array}$} \\
\hline & Frequency & $\%$ & Frequency & $\%$ \\
\hline Wrong & 71 & 49,3 & 1 & 0.7 \\
\hline Correct & 73 & 50.7 & 143 & 99.3 \\
\hline
\end{tabular}

Above Table 4 reveals that on the question, what happens when a patient, sitting in bed in a semi-upright position $\left(60^{\circ}\right)$, slides down? About $50.7 \%$ gave correct responses which increased to $99.3 \%$ correct responses after the ed- ucation of preventive pressure ulcer measurements.

Table 5: Which statement is correct? a. Soap can dehydrate skin and thus the risk of pressure ulcers is increased.b. Moisture from urine, faces, or wound drainage causes pressure ulcers. c. Shear is the force which occurs when the body slides and the skin sticks.

\begin{tabular}{|l|c|c|c|c|}
\hline Response & \multicolumn{2}{|c|}{$\begin{array}{c}\text { Knowledge } \\
\text { Before } \\
\text { education }\end{array}$} & \multicolumn{2}{c|}{$\begin{array}{c}\text { Knowledge } \\
\text { After } \\
\text { education }\end{array}$} \\
\hline & Frequency & $\%$ & Frequency & $\%$ \\
\hline Wrong & 33 & 22.9 & 2 & 1.5 \\
\hline Correct & 111 & 77.1 & 142 & 98.5 \\
\hline
\end{tabular}

Above Table 5 suggests that on the question, moisture from urine, faces, or wound drainage causes pressure ulcers, which was correctly replied by $77.1 \%$ in before education while $98.5 \%$ participants replied correctly after the education session.

Table 6: Which statement is correct? a. Recent weight loss which has brought a patient below his or her ideal weight increases the risk of pressure ulcers. b. Very obese patients using medication that decreases the peripheral blood circulation are not at risk of developing pressure ulcer. c. poor nutrition and age have no impact on tissue tolerance when the patient has normal weight.

\begin{tabular}{|l|c|c|c|c|}
\hline Response & \multicolumn{2}{|c|}{$\begin{array}{c}\text { Knowledge } \\
\text { Before } \\
\text { education }\end{array}$} & \multicolumn{2}{c|}{$\begin{array}{c}\text { Knowledge } \\
\text { After } \\
\text { education }\end{array}$} \\
\hline & Frequency & $\%$ & Frequency & $\%$ \\
\hline Wrong & 81 & 56.3 & 3 & 2.4 \\
\hline Correct & 63 & 43.8 & 141 & 97.6 \\
\hline
\end{tabular}

Above Table 6 reveals that on the question, recent weight loss which has brought a patient below his or her ideal weight increases the risk of pressure ulcers, where $43.8 \%$ gave correct responses which increased to $97.6 \%$ correct responses after the education of preventive pressure ulcer measurements.

Table 7: There is NO relationship between pressure ulcer risk and a. Age b. Dehydration c. Hypertension. 


\begin{tabular}{|l|c|c|c|c|}
\hline Response & \multicolumn{2}{|c|}{$\begin{array}{c}\text { Knowledge } \\
\text { Before } \\
\text { education }\end{array}$} & \multicolumn{2}{c|}{$\begin{array}{c}\text { Knowledge } \\
\text { After } \\
\text { education }\end{array}$} \\
\hline & Frequency & $\%$ & Frequency & $\%$ \\
\hline Wrong & 76 & 52.8 & 2 & 1.5 \\
\hline Correct & 68 & 47.2 & 142 & 98.5 \\
\hline
\end{tabular}

Above Table 7 suggests that on the question no relationship of hypertension with developing pressure ulcer which was correctly replied by $47.2 \%$ in before education while $98.5 \%$ participants replied correctly after the education session.

Table 8: Which statement is correct? a. A pressure ulcer extending down to the fascia is a grade 3 pressure ulcer. $\mathbf{b}$. A pressure ulcer extending through the under/lying fascia is a grade 3 pressure ulcer. c. A grade 3 pressure ulcer is always preceded by a grade 2 pressure ulcer.

\begin{tabular}{|l|c|c|c|c|}
\hline Response & \multicolumn{2}{|c|}{$\begin{array}{c}\text { Knowledge } \\
\text { Before } \\
\text { education }\end{array}$} & \multicolumn{2}{c|}{$\begin{array}{c}\text { Knowledge } \\
\text { After } \\
\text { education }\end{array}$} \\
\hline & Frequency & $\%$ & Frequency & $\%$ \\
\hline Wrong & 108 & 75 & 3 & 2.4 \\
\hline Correct & 36 & 25 & 141 & 97.6 \\
\hline
\end{tabular}

Above Table 8 reveals that on the question, that pressure ulcer extending through the under/lying fascia is a grade 3 pressure ulcer, in pre education only $25 \%$ gave correct responses which increased to $97.6 \%$ correct responses after the education of preventive pressure ulcer measurements.

Table 9: Which statement is correct? a. A blister on a patient's heel is a/ways a pressure ulcer of grade b. All grades (1,2,3, and 4) of pressure ulcers involve loss of skin layers. c. When necrosis occurs, it is a grade 3 or a grade 4 pressure ulcer.

\begin{tabular}{|l|c|c|c|c|}
\hline Response & \multicolumn{2}{|c|}{$\begin{array}{c}\text { Knowledge } \\
\text { Before } \\
\text { education }\end{array}$} & \multicolumn{2}{c|}{$\begin{array}{c}\text { Knowledge } \\
\text { After } \\
\text { education }\end{array}$} \\
\hline & Frequency & $\%$ & Frequency & $\%$ \\
\hline Wrong & 78 & 54.2 & 25 & 17.2 \\
\hline Correct & 66 & 45.8 & 119 & 82.8 \\
\hline
\end{tabular}

Above Table 9 suggests that on a question when necrosis occurs, it is a grade 3 or a grade 4 pressure ulcer which was correctly replied by $45.8 \%$ in before education while $82.8 \%$ participants replied correctly after the education session.

Table 10: Which statement is correct? a. Friction or shear may occur when moving a patient in bed. b. Superficial lesion, proceeded by nonblanch able erythema is probably a friction lesion. c. A kissing ulcer (copy lesion) is caused by pressure and shear.

\begin{tabular}{|l|c|c|c|c|}
\hline Response & \multicolumn{2}{|c|}{$\begin{array}{c}\text { Knowledge } \\
\text { Before } \\
\text { education }\end{array}$} & \multicolumn{2}{c|}{$\begin{array}{c}\text { Knowledge } \\
\text { After } \\
\text { education }\end{array}$} \\
\hline & Frequency & $\%$ & Frequency & $\%$ \\
\hline Wrong & 65 & 45.1 & 26 & 18 \\
\hline Correct & 79 & 54.9 & 118 & 82 \\
\hline
\end{tabular}

Above Table 10 reveals that on question, friction and shear causes' pressure ulcer, in pre educational session $54.9 \%$ gave correct responses which increased to $82 \%$ correct responses after the education of preventive pressure ulcer measurements.

Table 11: Which statement is correct? In a sitting position, pressure ulcers are most likely to develop on: a. Pelvic area, elbow and heel. b. Knee, ankle and hip. c. Hip, shoulder and heel.

\begin{tabular}{|l|c|c|c|c|}
\hline Response & \multicolumn{2}{|c|}{$\begin{array}{c}\text { Knowledge } \\
\text { Before } \\
\text { education }\end{array}$} & \multicolumn{2}{c|}{$\begin{array}{c}\text { Knowledge } \\
\text { After } \\
\text { education }\end{array}$} \\
\hline & Frequency & $\%$ & Frequency & $\%$ \\
\hline Wrong & 57 & 39.6 & 1 & 0.7 \\
\hline Correct & 87 & 60.4 & 143 & 99.3 \\
\hline
\end{tabular}

Above Table 11 suggests that on statement in a sitting position, pressure ulcers are most likely to develop on Hip, shoulder and heel, which was correctly replied by $60.4 \%$ in before education while $99.3 \%$ participants replied correctly after the education session.

Table 12: Which statement is correct? a. All patients at risk of pressure ulcers should have a systematic skin inspection once a week. b. The skin of patients seated in a chair, who cannot 
move themselves, should be inspected every two to three hours. c. The heels of patients who lie on a pressure redistributing surface should be observed minimum a day.

\begin{tabular}{|l|c|c|c|c|}
\hline Response & \multicolumn{2}{|c|}{$\begin{array}{c}\text { Knowledge } \\
\text { Before } \\
\text { education }\end{array}$} & \multicolumn{2}{c|}{$\begin{array}{c}\text { Knowledge } \\
\text { After } \\
\text { education }\end{array}$} \\
\hline & Frequency & $\%$ & Frequency & $\%$ \\
\hline Wrong & 111 & 77.1 & 0 & 0 \\
\hline Correct & 33 & 22.9 & 144 & 100 \\
\hline
\end{tabular}

Above Table 12 reveals that a question on frequent assessment of skin to prevent pressure ulcer in pre-education only $22.9 \%$ gave correct responses which increased to $100 \%$ correct responses after the education of preventive pressure ulcer measurements.

Table 13: Which statement is correct? a. Risk assessment tools identify all high risk patients in need of prevention. b. The use of risk assessment scales reduces the cost of prevention. c. A risk assessment scale may not accurately predict the risk of developing a pressure ulcer and should be combined with clinical judgment.

\begin{tabular}{|l|c|c|c|c|}
\hline Response & \multicolumn{2}{|c|}{$\begin{array}{c}\text { Knowledge } \\
\text { Before } \\
\text { education }\end{array}$} & \multicolumn{2}{c|}{$\begin{array}{c}\text { Knowledge } \\
\text { After } \\
\text { education }\end{array}$} \\
\hline & Frequency & $\%$ & Frequency & $\%$ \\
\hline Wrong & 101 & 70.1 & 4 & 3 \\
\hline Correct & 43 & 29.9 & 140 & 97 \\
\hline
\end{tabular}

Above Table 13 suggests that risk assessment tools identify all high risk patients in need of prevention which was correctly replied by $29.9 \%$ in before education while $97 \%$ participants replied correctly after the education session.

Table 14: Which statement is correct? a. The risk of pressure ulcer development should be assessed daily in all nursing home patients. b. Absorbing pads should be placed under the patient to minimize the risk of pressure ulcer development. c. A patient with a history of pressure ulcer runs a higher risk of developing new pressure ulcers.

\begin{tabular}{|l|c|c|c|c|}
\hline Response & \multicolumn{2}{|c|}{$\begin{array}{c}\text { Knowledge } \\
\text { Before } \\
\text { education }\end{array}$} & \multicolumn{2}{c|}{$\begin{array}{c}\text { Knowledge } \\
\text { After } \\
\text { education }\end{array}$} \\
\hline & Frequency & $\%$ & Frequency & $\%$ \\
\hline Wrong & 61 & 42.4 & 48 & 33.5 \\
\hline Correct & 83 & 57.6 & 96 & 66.5 \\
\hline
\end{tabular}

Above Table 14 reveals that on a question of above statement, pre education $57.6 \%$ gave correct responses which increased to $66.5 \%$ correct responses after the education of preventive pressure ulcer measurements.

Table 15 Paired sample t test for knowledge score among Nurses before and after Education

\begin{tabular}{lcc}
\hline Variables & Mean \pm S.D & P value \\
\hline $\begin{array}{l}\text { Nurses knowledge } \\
\text { before education }\end{array}$ & $5.73 \pm 1.488$ & .000 \\
$\begin{array}{l}\text { Nurses knowledge } \\
\text { after education }\end{array}$ & $12.01 \pm .908$ & \\
& &
\end{tabular}

Table 15 findings represent the overall knowledge score on the knowledge base questionnaire regarding the preventive measures of pressure ulcer. All Nurses were asked 13 knowledge based questions before an education session and then after providing education about the pressure ulcer prevention among the prolong bed ridden patients. The findings suggest that average pre education score was $5.73 \pm 1.488$ out of total 13 , whereas the average post education score was found to be $12.01 \pm .908$ out of 13 total which represents a clear prominent difference after providing the education to nurses. There was a significant difference between the mean knowledge score about the pressure ulcer preventive measures among nurses before and after education sessions. $\mathrm{P}$ value was 0.000 which was less than .001 shows a significant difference in mean knowledge score before and after the education.

\section{Discussion}

The current study tested nurses' knowledge on the subject of preventive methods of pressure ulcers among nurses. A low average score 5.75 out of 13 was found which shows a very low level of knowledge among nurses. A similar study was conducted in Nigeria to weigh the at- 
titude, practice and knowledge of PU preclusion in University of Maiduguri Teaching Hospital. The study was a cross sectional descriptive survey of 99 nurses; data was collected through a self-developed and authenticated questionnaire tool. The results showed low level of knowledge of PU prevention, attitudes and practices among nurses (Uba et al., 2015).

The findings of this current study reveal that there was a significant difference between the mean knowledge score about the pressure ulcer preventive measures among nurses before and after education sessions. $\mathrm{P}$ value is 0.000 which is less than .001 shows a significant difference in mean knowledge score before and after the education. Another similar study finding revealed that nurses' knowledge regarding the pressure ulcer preventive measures was increased with the help of education programs among nurses working in hospital (Saleh et al., 2012). The result of a previous study revealed same kind of results where a positive association of education regarding pressure ulcer prevention protocol was found with nurses' knowledge to ward pressure ulcer prevention. The pretest result indicated that nurses' knowledge was a moderate level $(74.05 \%$ $\mathrm{SD} \pm 13.499)$, nurses attitude was positive (42\% $\mathrm{SD} \pm 4.767)$ and nurses practice was $(67 \% \mathrm{SD} \pm$ 2.983). However, the mean percentage of all posttest showed a significant (Gunningberg, Hommel, Bååth, \& Idvall, 2013). According to another study Adherence to the preventive measures showed a significant increase $(11.7 \%)$ between the first month of the program and the final month $(58.5 \%)$ of the assessment. Initial PU rate was 20.9 , with a decrease in the rate to 14.0 per 1000 bed occupancy days $(\mathrm{P}<.05)$ after the risk management program (Araya \& Febré, 2017).

Limitations: The sample proportion is small and from a precise circumscribed group therefore the results cannot be comprehensive to the larger population.

Conflict of interest: There was no conflict of interest in this study.

Acknowledgement: Taking the opportunity I am obliged to sincerely thank Sir Muhammmad Afzal (Principal Lahore School of Nursing); special thanks to my worthy teacher Miss Sana Sehar; moreover, I have no adequate words to express my thanks but my heart is still full of the favors received from every person.

\section{Discussion}

Pressure ulcers remain a significant problem in the health care system. Pressure ulcers prevention educational program was effective in increasing the knowledge of nurses; improving the practices related to PUs care; decreasing the incidence of pressure ulcers (PUs) occurrence among patients. In this current study, an apparent barrier for using pressure ulcer prevention intervention (PUPI) is lack of knowledge in clinical practice. Nurses are not fully aware the importance of using up-to-date information. In this study, pre-knowledge tests of nurses was poor scored. Most nurses have low competency level to demonstrate pressure ulcer prevention intervention (PUPI). Knowledge base practices have improved the quality of life and care. In the current study, post-test knowledge of nurses after seminar, lecture and literature which was given by the researcher, was improved and most nurses get high marks in post-test session.

\section{References:}

1. ANDRADE EM, CAVALCANTI PA, MONTEIRO, AKC, MONTEIRO AKC, LUZ MHB, NETO J M, MENDES IA (2014) Effect of an educational intervention by attendance and at distance on nurses' knowledge about pressure ulcer. Creative Education, 5(18), 1673.

2. ARAYA IF, FEBRE N (2017) Impact of interventions in the pressure ulcer rate. Revista de calidad asistencial: organo de la Sociedad Espanola de Calidad Asistencial, 32(6), 322327.

3. BRUNNER LS, SUDDARTH DS, BARE BG, BOYER MJ, SMELTZER SCC (1988) Textbook of medical- surgical nursing (Vol. 2): Lippincott.

4. COX J, ROCHE S, VAN WYNEN E (2011) The effects of various instructional methods on retention of knowledge about pressure ulcers among critical care and medical-surgical nurses. The journal of continuing education in nursing, 42(2), 71-78.

5. DE MEYER D, VERHAEGHE S, VAN HECKE A, BEECKMAN D (2019) Knowledge of nurses and nursing assistants about pressure ulcer prevention: A survey in 16 Belgian hospitals using the PUKAT 2.0 tool. Journal of Tissue Viability. 
6. GRAY-SIRACUSA K, SCHRIER L (2011) Use of an intervention bundle to eliminate pressure ulcers in critical care. Journal of nursing care quality, 26(3), 216-225.

7. GUNNINGBERG L, HOMMEL A, BAATH C, IDVALL E (2013) The first national pressure ulcer prevalence survey in county council and municipality settings in Sweden. Journal of evaluation in clinical practice, 19(5), 862-867.

8. HSU M-Y, TSAO W-Y, SUNG H-C (2013) The effectiveness of educational programs in promoting nurses' knowledge of pressure ulcers: a systematic review protocol. JBI Database of Systematic Reviews and Implementation Reports, 11(5), 132-139.

9. LEVINE JM, AYELLO EA, ZULKOWSKI KM, FOGEL J (2012) Pressure ulcer knowledge in medical residents: an opportunity for improvement. Advances in skin \& wound care, 25(3), 115-117.

10. MASOUMI N, MASOUMI B, SHOUJAEI F, SHARAFI SF (2015) A review of postural balance and its related factors in the elderly.

11. MOHAMED SA, WEHEIDA SM (2015) Effects of implementing educational program about pressure ulcer control on nurses' knowledge and safety of immobilized patients. Journal of Nursing Education and Practice, 5(3), 12.

12. SALEH MY, QADDUMI JAS, ANTHONY D (2012) An interventional study on the effects of pressure ulcer education on Jordanian registered nurses' knowledge and practice. Procedia-Social and Behavioral Sciences, 47, 2196-2206.

13. SMITH D, WAUGH S (2009) Research study: an assessment of registered nurses' knowledge of pressure ulcers prevention and treatment. Kansas Nurse, 84(1), 3.

14. UBA M, ALIH F, KEVER R, LOLA N (2015) Knowledge, attitude and practice of nurses toward pressure ulcer prevention in University of Maiduguri Teaching Hospital, Borno State, North- Eastern, Nigeria. International Journal of Nursing and Midwifery, 7(4), 54-60.

15. VANDERWEE K, CLARK, M, DEALEY C, GUNNINGBERG L, DEFLOOR T (2007) Pressure ulcer prevalence in Europe: a pilot study. Journal of evaluation in clinical practice, 13(2), 227-235.

16. ZEB A, ILYAS SM, KASHIF M, KOMPAL R., DARAIN, H, BAHADAR S (2015) Knowledge And Attitudes On Pressure Ulcer Prevention Among Nurses Working In Neurological Departments In Tertiary Care Hospitals Of Peshawar: A Multicenter Study. Annals of Allied Health Sciences (PMDC Registered), 1(2), 49-53. 